\title{
The potential influence of KIR cluster profiles on disease patterns of Canadian Aboriginals and other indigenous peoples of the Americas
}

\author{
Julia D Rempel ${ }^{\star, 1,3}$, Kim Hawkins ${ }^{1}$, Erin Lande $^{2}$ and Peter Nickerson ${ }^{2,3}$
}

Genetic differences in immune regulators influence disease resistance and susceptibility patterns. There are major health discrepancies in immune-mediated diseases between Caucasians and Canadian Aboriginal people, as well as with other indigenous people of the Americas. Environmental factors offer a limited explanation as Aboriginal people also demonstrate a rare resistance to chronic hepatitis C virus infection. Killer immunoglobulin-like receptors (KIRs) are known modulators of viral responses and autoimmune diseases. The possibility that variation in KIR cluster profiles contribute to the health outcomes of Aboriginal people was evaluated with Canadian Caucasian ( $n=93$, population controls) and Aboriginal $(n=86)$ individuals. Relative to Caucasians, the Aboriginal KIR cluster displayed a greater immune activating phenotype associated with genes of the B haplotype situated within the telomeric region. In conjunction, there was a decrease in the genes of the B haplotype from the centromeric region. Caucasian and Aboriginal cohorts further demonstrated distinct genotype and haplotype relationships enforcing the disconnect between the B haplotype centromeric and telomeric regions within the Aboriginal population. Moreover, Caucasian KIR cluster patterns reflected studies of Caucasians globally, as well as Asians. In contrast, the unique pattern of the Canadian Aboriginal cohort mirrored the phenotype of other indigenous peoples of the Americas, but not that of Caucasians or Asians. Taken together, these data suggest that historically indigenous peoples of the Americas were subject to immune selection processes that could be influencing the current disease resistance and susceptibility patterns of their descendents. European Journal of Human Genetics (2011) 19, 1276-1280; doi:10.1038/ejhg.2011.114; published online 6 July 2011

Keywords: pro-inflammatory immunity; ethnicity; KIR centromeric; KIR telomeric

\section{INTRODUCTION}

The immune system is largely regulated by cytokines and various receptor interactions. Killer immunoglobulin-like receptors (KIRs) participate in regulating the activity of natural killer cells and certain T-cell subsets, thereby affecting innate and adaptive immunity. This cellular regulation can influence the course of infections, autoimmunity, cancers and other diseases. ${ }^{1-5}$

The KIR cluster contains 15 genes and 2 pseudogenes, ${ }^{6}$ which are segregated within the centromeric and telomeric portions of the cluster. The centromeric and telomeric regions are flanked by framework genes KIR3DL3 and KIR3DL2, respectively. These regions are also separated by framework genes KIR3DP1 and KIR2DL4. The framework genes are highly conserved throughout human populations. The individual KIR genes inside these regions code for either activating or inhibitory receptors whose interaction with corresponding MHC ligands on target cells can, respectively, promote or inhibit cell function. Individual KIR gene associations have been made with specific disease resistance and susceptibility within a population. ${ }^{1-4,7}$ In addition, population differences in gene and genotypes profiles suggest that KIR clusters may contribute to distinct disease outcomes between ethnic populations. ${ }^{8-10}$ Considerably, less is understood about the disease interactions of KIR haplotypes. KIR genes have been designated into inheritable A or B haplotypes. Haplotype A is defined by the presence of either KIR2DL3 or KIR $2 D L 1$ in the centromeric portion and KIR3DL1 or KIR2DS4 in the telomeric region. ${ }^{6}$ In contrast, the $\mathrm{B}$ haplotype is defined by KIR2DS2 or $K I R 2 D L 2$ in the centromeric region and KIR3DS1, KIR2DL5A, KIR2DL5B, KIR2DS5 or KIR2DS1 in the telomeric segment. Centromeric and telomeric influences can also provide another level of complexity. ${ }^{11,12}$

Ethnically defined disease burdens have been largely attributed to environmental factors. ${ }^{13,14}$ However, epidemiological data on reduced rates of progression to chronic hepatitis $\mathrm{C}$ infection in North American Aboriginal people despite similar environmental factors ${ }^{15-18}$ suggest that underlying biological events participate in populationspecific disease outcomes. In an effort to address genetic factors that might contribute to these differences in health outcomes, we evaluated the KIR genes of Caucasian and Aboriginal populations residing in the Canadian province of Manitoba.

\section{METHODS}

Subjects

This study was approved by and conducted according to the policies of the University of Manitoba Ethics Board. It was also performed in discussion with the Assembly of Manitoba Chiefs, Health Information Research Committee. Canadian Aboriginal people consist of First Nation, Inuit and Métis. In this study, Caucasian ( $n=93)$ and Aboriginal $(n=86)$ adults were recruited through local advertisement. Caucasian individuals defined as being of European

\footnotetext{
1Section of Hepatology, Department of Medicine, University of Manitoba, Winnipeg, MB, Canada; ${ }^{2}$ Section of Transplant Immunology, Department of Medicine, University of Manitoba, Winnipeg, MB, Canada; ${ }^{3}$ Department of Immunology, University of Manitoba, Winnipeg, MB, Canada

*Correspondence: Dr JD Rempel, Departments of Medicine and Immunology, University of Manitoba, 804D-715 McDermot Ave, Winnipeg, MB, Canada R3E 3P4 Tel: +1 204789 3825; Fax: +1 204789 3971; E-mail: jdrempel@cc.umanitoba.ca
}

Received 26 October 2010; revised 19 April 2011; accepted 21 April 2011; published online 6 July 2011 
descent acted as a population control. First Nation individuals were predominately from the Oji-Cree First Nation (70\%). The remaining Aboriginal individuals were primarily Oji-Cree, Ojibway, Cree or Métis. All individuals were negative for serologic evidence of $\mathrm{HCV}$ exposure or chronic HBV infection, and were not receiving medications for other chronic infections. The percentage of male participants was $39.3 \%$ in the Caucasian cohort and $45.5 \%$ in the Aboriginal cohort (ns, $\chi^{2}$, Pearson's correction). The median age (range) was also not significantly different; $43(22-75)$ and 36 (20-61) in the Caucasian and Aboriginal cohorts, respectively.

\section{Genetic analysis}

After the signing of consent, whole blood was donated. Genomic DNA was extracted from isolated buffy coat cells following the QIAGEN protease digestion and absorption onto QIAamp silica-gel (Qiagen, Mississauga, ON, Canada). The product was eluted on a column to enhance the purity and concentration of the extracted DNA. The presence of KIR genes was determined using the Dynal Biotech (Brown Deer, WI, USA) Pel-Freez SSP UniTray KIR genotyping kit according to the manufacturer's instructions. Gene products were visualized with UV light on a transilluminator and photographed for subsequent analysis. In this manner, the presence or absence of the following KIR genes was assessed: KIR2DL1, KIR2DL2, KIR2DL3, KIR2DL5A, KIR2DL5B, KIR2DS1, KIR2DS2, KIR2DS3, KIR2DS4, KIR2DS5, KIR3DL1, KIR3DS1 and KIR2DP1, as well as framework genes KIR2DL4, KIR3DL2, KIR3DL3 and KIR3DP1.

\section{Data analysis}

KIR gene frequencies for a population were calculated as $1-(\sqrt{ } 1-f)$, where $f$ equals the observed KIR gene frequency. Differences in KIR cluster parameters between Caucasian and Aboriginal cohorts were analyzed by $\chi^{2}$, Pearson's exact test. A $P<0.01$ was considered as statistically significant. Linkage disequilibrium was assessed as $D^{\prime}$, a statistical calculation of linkage between two single nucleotide polymorphisms (SNPs) (SNP \& Variation Suite 7; Golden Helix Incorporated, Bozeman, MT, USA). An analysis of the association between two SNPs, $r^{2}$, was also performed. Haplotype designations were made as previously detailed. ${ }^{19,20}$ (1) Framework genes were recognized as homozygous. (2) For the centromeric portion of the cluster, as KIR2DL3 and
KIR2DL2 are thought to be alleles of the same locus, if only one was present, then that allele was assumed to be homozygous and the centromeric portion was assumed to be an AA or BB haplotype, respectively. If both KIR2DL3 and KIR2DL2 were present, the cluster was considered to be an AB haplotype. (3) For the telomeric portion of the cluster, as KIR3DL1 and KIR3DS1 are considered alleles of the same locus, if only one was present, then homozygosity was assumed and the telomeric portion of the cluster was identified as an AA or $\mathrm{BB}$ haplotype, respectively. If both were present, the cluster was considered to be an AB haplotype. (4) Independent of haplotype, KIR2DS4 was considered homozygous if other KIR2DS genes were not present. However, if another KIR2DS gene was apparent in the presence of an $\mathrm{AB}_{\text {telomeric }}$ haplotype, the KIR2DS4 was considered to be present on the haplotype A and absent on the haplotype B.

\section{RESULTS AND DISCUSSION}

Indigenous people have a differential presence of KIR $B$ haplotype genes

Caucasian and Aboriginal populations differ in the prevalence of certain infectious diseases, autoimmunities and cancers. To better understand the impact of underlying biology in disease demographics, KIR gene profiles were assessed in Caucasian $(n=93)$ and Aboriginal $(n=86)$ individuals. As expected, the framework genes KIR2DL4, KIR3LD2, KIR3DL3 and KIR3DP1, and pseudogene KIR2DP1 were present with few exceptions. In addition, KIR2DL1, KIR2DL3, KIR2DS4 and KIR3DL1 genes within the A haplotype were present in over $84 \%$ of all individuals, a finding paralleled in other ethnic groups (Table 1; see Supplementary Table 1 for gf differences between Manitoban populations and details regarding the presence of KIR2DL5A and KIR2DL5B in these cohorts). ${ }^{19-22}$

Conversely, marked variation was apparent in the genes associated with the B haplotype. Compared with Caucasian samples, the Aboriginal population exhibited a decreased presence of $\mathrm{B}$

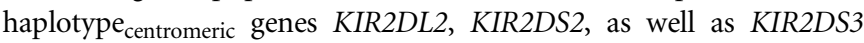
(Table 1). This aligned with the contrasting homogeneity of the A and

Table 1 Aboriginal gene profiles reflect that of other indigenous people of the Americas

\begin{tabular}{|c|c|c|c|c|c|c|c|c|c|c|}
\hline \multirow[b]{2}{*}{ KIR gene } & \multicolumn{2}{|c|}{ Manitoba } & \multicolumn{2}{|c|}{ Caucasian } & \multicolumn{4}{|c|}{ Mexico } & \multicolumn{2}{|c|}{ Argentina } \\
\hline & $\begin{array}{c}C A \\
(\mathrm{n}=93)\end{array}$ & $\begin{array}{c}A B^{\mathrm{a}} \\
(\mathrm{n}=86)\end{array}$ & $\begin{array}{l}\text { Greece }^{b} \\
(n=233)\end{array}$ & $\begin{array}{l}\text { Argentina } \\
(\mathrm{n}=402)\end{array}$ & $\begin{array}{c}M e \\
(n=86)\end{array}$ & $\begin{array}{c}H u \\
(n=73)\end{array}$ & $\begin{array}{c}P u \\
(n=53)\end{array}$ & $\begin{array}{c}T a \\
(\mathrm{n}=65)\end{array}$ & $\begin{array}{c}W i \\
(\mathrm{n}=101)\end{array}$ & $\begin{array}{c}C h \\
(n=54)\end{array}$ \\
\hline \multicolumn{11}{|c|}{ Centromeric } \\
\hline $2 \mathrm{DL} 1^{\mathrm{C}}$ & 99 & 98 & 89 & 96 & 100 & 100 & 100 & 100 & 84 & 91 \\
\hline $2 \mathrm{DL} 3^{\mathrm{C}}$ & 90 & 95 & 88 & 87 & 100 & 100 & 100 & 100 & 84 & 87 \\
\hline $2 \mathrm{DL} 2^{\mathrm{d}}$ & 55 & $30 * *$ & 50 & 56 & 43 & 34 & 34 & 34 & 62 & 44 \\
\hline $2 \mathrm{DS} 2^{\mathrm{d}}$ & 56 & $30 * *$ & 54 & 55 & 44 & 34 & 34 & 34 & 61 & 41 \\
\hline $2 \mathrm{DS} 3^{\mathrm{d}}$ & 39 & $7 * * *$ & 37 & 29 & 17 & 16 & 4 & 0 & 3 & 6 \\
\hline \multicolumn{11}{|l|}{ Telomeric } \\
\hline $2 \mathrm{DS} 4^{\mathrm{C}}$ & 97 & 84 & 88 & 95 & 98 & 98 & 98 & 98 & 89 & 87 \\
\hline $3 D L 1^{c}$ & 96 & 84 & 90 & 95 & 99 & 97 & 98 & 98 & 89 & 87 \\
\hline $3 D S 1^{d}$ & 41 & $70^{* *}$ & 46 & 42 & 42 & 56 & 62 & 66 & 54 & 57 \\
\hline $2 D L 5^{d}$ & 40 & $69^{*}$ & NT & 56 & 49 & 56 & 62 & 66 & 53 & 59 \\
\hline $2 \mathrm{DS} 1^{\mathrm{d}}$ & 39 & $69 * * *$ & 43 & 46 & 42 & 56 & 62 & 66 & 53 & 57 \\
\hline $2 D S 5^{d}$ & 32 & $64^{* * *}$ & 21 & 36 & 40 & 48 & 62 & 66 & 52 & 56 \\
\hline$p^{e}$ & NA & $<0.001$ & NS & NS & $<0.001$ & $<0.001$ & $<0.001$ & $<0.001$ & $<0.001$ & $<0.001$ \\
\hline$P^{f}$ & $<0.001$ & NA & $<0.001$ & $<0.001$ & $<0.001$ & NS & NS & NS & $<0.001^{\mathrm{g}}$ & NS \\
\hline
\end{tabular}

Abbreviations: AB, Aboriginal; CA, Caucasian; Ch, Chiriguanos; Hu, Huichol; Me, Mestizo; NA, not applicable; NS, not significant; Pu, Purepecha; Ta, Tarahumara; Wi, Wichis.

aSignificant differences between Caucasian and Aboriginal cohorts shown ${ }^{*} P<0.05,{ }^{* *} P<0.01,{ }^{* * *} P<0.001$.

Correspong

c,dGenes within A and B haplotypes, respectively.

e,fSignificant difference of KIR gene profiles of other cohorts with the Manitoban Caucasian and Aboriginal cohorts, respectively.

significant difference between $\mathrm{AB}$ and Wi for centromeric segment alone $P<0.001$, for telomeric segment alone $P>0.05$ (NS) 
B haplotypes for the centromeric section (see Supplementary Table 2). KIR2DL3 and KIR2DL2 are alleles of the shared locus within A and B haplotypes, respectively. The KIR2DL3 allele was present in a high proportion of the Caucasian (90.0\%) and Aboriginal (95.3\%) samples (Table 1). However, relative to the Caucasian cohort this allele was more often present in a homogenous manner in the Aboriginal cohort $(P<0.05$; see Supplementary Table 2$)$ corresponding to the lower presence of KIR2DL2 in this population (Table 1). Concomitantly, the opposite was observed with the telomeric KIR3DL1 and KIR3DS1 alleles. Here, KIR3DL1 displayed greater homogeneity in the Caucasian cohort (see Supplementary Table 2; $P<0.01$ ). This was supported by the reduced presence of the KIR3DS1 allele in the Caucasian, relative to the Aboriginal, population (Table 1). Concomitantly, there is an increased

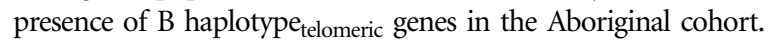

To evaluate the potential distribution of the Aboriginal KIR phenotype, the Manitoban KIR gene profiles were analyzed against previously published studies (Table 1). The gene pattern from the Caucasian cohort paralleled Caucasians from other continents; ${ }^{19,23}$ whereas, the Aboriginal gene profile bore similarity to patterns from other indigenous peoples of the Americas. ${ }^{19,20}$ The resemblance was particularly acute with respect to the genes from the B haplotype. As with the Aboriginal population, the reduced presence of the $\mathrm{B}_{\text {centromeric }}$ genes, coupled with the prominence of the $\mathrm{B}_{\text {telomeric }}$ genes was also observed in other American indigenous peoples.

\section{Manitoban Aboriginal genotypes parallel those of other American indigenous peoples}

The Caucasian and Aboriginal KIR genotypes were numbered according to the global prevalence as per the meta-analysis published by Yawata et al. ${ }^{8}$ Reflecting this global prevalence, genotypes 1 and 2 were foremost in our Caucasian cohort (Table 2; Supplementary Figure 1 for full description of genotypes and six genotypes designated N01-N06 not reported by Yawata et al). The dominant genotype in the Aboriginal population, however, was genotype 4 (32.6\%). Genotypes 2 and 3 consisting of a quarter of the Caucasian genotypes were rare in the Aboriginal population (2.3\%).

The distinctiveness of the Manitoban Aboriginal KIR genotype profile was further apparent when compared with other indigenous populations (Table 2). Manitoban Caucasian genotypes were analogous to Caucasian profiles from other continents, and were also similar to East and West Asian profiles. ${ }^{8}$ Conversely, genotypes 4, 1 and 8 accounted for $72 \%$ of the Aboriginals genotypes. This hierarchy was comparable to the Mexican Purepecha and Tarahumara, and
Argentinean Chiriguanos. ${ }^{19,20}$ Interestingly, all the indigenous populations, including the Huichol and Wichis, had an increased presence of genotypes 4 and/or 8 that possess genes belonging within the $\mathrm{B}_{\text {telomeric }}$ segment. This occurred simultaneously to a muted presence of genotypes 2 and 3 with limited connections to the $B_{\text {telomeric }}$ segment. Indeed, the genotypes with activating genes (KIR3DS1, KIR2DS1 and KIR2DS5) belonging to the haplotype $\mathrm{B}_{\text {telomeric }}$ in a minority of Caucasian samples (36.6\%), emerged with a high frequency in Aboriginal counterparts (67.4\%, $P<0.05$; Supplementary Figure 1). A similar finding was observed with the Yucpa, Bari and Warao Amerindians from Venezuela, where 72.1, 65.2 and $70.0 \%$ of the genotypes, respectively, possessed the activating genes belonging to the haplotype $\mathrm{B}_{\text {telomeric. }}{ }^{24}$

\section{Caucasian and Aboriginal haplotype analysis}

Despite these differences between ethnic cohorts, there appeared a high degree of linkage $\left(D^{\prime}=1.00\right)$ for genes within the centromeric portion for both the Caucasian $\left(P=1.5 \times 10^{-18}\right)$ and Aboriginal $\left(P=3.0 \times 10^{-19}\right)$ populations (Table 3$)$. The exception was the KIR2DS3 gene which interacted with other centromeric genes with a $D^{\prime}=0.780\left(P=2.5 \times 10^{-8}\right)$ in the Caucasian cohort. This interaction was further diminished in the Aboriginal cohort $\left(D^{\prime}=0.272, P>0.05\right)$. The uniqueness of the KIR2DS3 interaction may reflect the lower percentage of KIR2DS3 (39\%) within the Caucasian cohort and its further reduced presence $(7 \%)$ in the Aboriginal genome. The telomeric segment also demonstrated strong intra-regional interactions for the Caucasian $\left(D^{\prime}=0.972, P=6.2 \times 10^{-16}\right)$ and Aboriginal $\left(D^{\prime}=1.00, P=6.2 \times 10^{-18}\right)$ populations. These linkages suggest that genes within either the centromeric region (except for KIR2DS3) or the telomeric region are generally inherited as a regional unit.

In contrast, between centromeric and telomeric segments linkage was lacking within Caucasian samples $\left(D^{\prime}=0.170, P>0.05\right)$, but was still notable within the Aboriginal population $\left(D^{\prime}=0.678\right.$, $\left.P=5.0 \times 10^{-4}\right)$. KIR2DS3 again displayed a differential interaction with genes of the telomeric region.

Due to these interactions, A and B haplotypes were analyzed relative to the centromeric and telomeric positions. ${ }^{11}$ Compared with the Caucasian cohort, there was a reduced prevalence of the AB-AA haplotype in the Aboriginal cohort ( 18.3 vs $2.3 \%, P<0.001)$. Within the Aboriginal population $B_{\text {centromeric }}$ haplotypes were present only in combination with a $B_{\text {telomeric }}$ haplotype counterpart, with the exception of genotype 2 (see Supplementary Figure 1). Conversely,

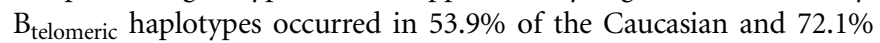

Table 2 Indigenous people of the Americas display a unique genotype prevalence

\begin{tabular}{|c|c|c|c|c|c|c|c|c|c|c|c|c|c|c|}
\hline \multirow[b]{2}{*}{ Order $^{a}$} & \multirow[b]{2}{*}{$C A$} & \multirow[b]{2}{*}{$A B$} & \multicolumn{5}{|c|}{ Meta-analysis ${ }^{\mathrm{b}}$} & \multicolumn{4}{|c|}{ Mexico } & \multicolumn{3}{|c|}{ Argentina } \\
\hline & & & All & $C A$ & $E A$ & $W A$ & $A f$ & $M e$ & $\mathrm{Hu}$ & $P u$ & $\mathrm{Ta}$ & $C A$ & Wi & $\mathrm{Ch}$ \\
\hline 1 & 24.7 & $25.6^{c}$ & 27 & 31.2 & 14.9 & 40.6 & 35.5 & 39.4 & 41 & 34 & 24.6 & 24 & 30.7 & 31.5 \\
\hline 2 & 18.3 & 2.4 & 11.5 & 14.9 & 9.1 & 10 & 8.1 & 12.8 & 2.7 & 3.8 & 9.2 & 14 & 12.9 & 5.6 \\
\hline 3 & 7.5 & 0 & 7.5 & 6.7 & 9.6 & 3.1 & 11.3 & 5.8 & 0 & 0 & 0 & 5.7 & 0 & 0 \\
\hline 4 & 10.8 & 32.6 & 6.3 & 7.2 & 4.4 & 8.1 & 6.5 & 16.3 & 15 & 30.2 & 41.5 & 14 & 5 & 16.7 \\
\hline 8 & 4.3 & 14 & 2.1 & 3 & 1.4 & 2.5 & 0 & 12.8 & 22 & 23 & 23 & 5 & 30.7 & 13 \\
\hline$P^{d}$ & NA & $<0.001$ & NS & NS & NS & NS & $<0.02$ & $<0.001$ & $<0.001$ & $<0.001$ & $<0.001$ & NS & $<0.001$ & $<0.001$ \\
\hline$p^{e}$ & $<0.001$ & NA & $<0.001$ & $<0.001$ & $<0.001$ & $<0.001$ & $<0.001$ & $<0.02$ & $<0.02$ & NS & NS & $<0.001$ & $<0.001$ & NS \\
\hline
\end{tabular}

Abbreviations: AB, Aboriginal; Af, African; CA, Caucasian; Ch, Chiriguanos; EA, East Asian; Hu, Huichol; Me, Mestizo; NA, not applicable; NS, not significant; Pu, Purepecha; Ta, Tarahumara; WA, West Asian; Wi, Wichis.

aThe genotype order according to meta-analysis by Yawata et al observed in 989 individuals from four studies.

${ }^{b}$ Corresponding references: Meta-analysis, Yawata et al ${ }^{8}$; Argentina, Flores et a ${ }^{19}$; Mexico, Gutierrez-Rodriguez et al. ${ }^{20}$

cPercent of individuals in that population with that genotype.

d,esignificant difference from Manitoban Caucasian and Aboriginal cohorts, respectively. 
Table 3 Centromeric and telomeric regional interactions

\begin{tabular}{llllll}
\hline Ethnicity & Gene/region $^{\mathrm{a}}$ & Region $^{\mathrm{b}}$ & $D^{\mathrm{c}}$ & $\mathrm{r}^{2 \mathrm{~d}}$ & P-value $^{\mathrm{e}}$ \\
\hline Caucasian & Centromeric $^{\mathrm{f}}$ & Centromeric & 1.000 & 0.893 & $1.5 \times 10^{-18}$ \\
& 2DS3 & Centromeric & 0.780 & 0.397 & $2.5 \times 10^{-8}$ \\
& Telomeric & Telomeric & 0.973 & 0.767 & $6.2 \times 10^{-16}$ \\
& Centromeric & Telomeric & 0.170 & 0.022 & 0.183 \\
& 2DS3 & Telomeric & 0.365 & 0.170 & 0.0024 \\
& Centromeric & Centromeric & 1.000 & 0.960 & $3.0 \times 10^{-19}$ \\
& & Centromeric & 0.272 & 0.018 & 0.207 \\
& Telomeric & Telomeric & 1.000 & 0.865 & $6.2 \times 10^{-18}$ \\
& Centromeric & Telomeric & 0.678 & 0.138 & $5.0 \times 10^{-4}$ \\
& 2DS3 & Telomeric & 0.115 & 0.001 & 0.771 \\
\hline
\end{tabular}

a,b The region (a) indicated was assessed for interactions within or with gene/region (b). ' $D$ ' is a measure of the statistical significance for gene interactions. Median $D^{\prime}$ for genes indicated is shown.

dMedian $r^{2}$ values of the pairwise associations are shown for the genes indicated.

e Median $P$-values for genes indicated shown according to $\chi^{2}$, Pearson corrected.

${ }^{f}$ Centromeric region analysis does not include 2DS3 which is assessed separately.

Table 4 Aboriginal individuals have an increased prevalence of $B_{\text {telomeric }}$ haplotypes

\begin{tabular}{|c|c|c|c|c|}
\hline \multicolumn{2}{|c|}{ Haplotype a } & \multirow[b]{2}{*}{ Caucasian } & \multirow[b]{2}{*}{ Aboriginal ${ }^{\mathrm{b}}$} & \multirow[b]{2}{*}{$\mathrm{P}$-value ${ }^{\mathrm{C}}$} \\
\hline Centomeric & Telomeric & & & \\
\hline$A A$ & $A A$ & 25.8 & 25.6 & NS \\
\hline AA & $A B$ & 15.1 & 34.9 & NS \\
\hline$A B$ & AA & 19.4 & 2.3 & $<0.001$ \\
\hline$A B$ & $A B$ & 35.5 & 20.9 & $<0.05$ \\
\hline AA & BB & 1.1 & 7 & \\
\hline$A B$ & BB & 2.2 & 7 & $<0.01$ \\
\hline BB & $A B$ & 1.1 & 0 & NS \\
\hline BB & BB & 0 & 2.3 & NS \\
\hline
\end{tabular}

aHaplotypes A and B were determined as per Methods.

bignificant difference in the prevalence of all haplotypes between ethnic cohorts, $P<0.001$.

'Significant difference in the prevalence of individual haplotypes between cohorts shown.

of the Aboriginal populations $(P<0.001$; Table 4$)$. The greater presence of the $\mathrm{B}_{\text {telomeric }}$ haplotypes in the Aboriginal cohort was also evident in that only $3.3 \%$ Caucasian population possessed the rare $\mathrm{BB}_{\text {telomeric }}$ haplotype, in contrast to $16.3 \%$ of the Aboriginal cohort $(P<0.01)$.

\section{Current KIR genetic profiles may reflect historical immune selection}

The similarity in the KIR cluster within indigenous people of the Americas likely represents a historical selection bias. One mechanism to introduce such a bias would be a common ancestry. Genetic studies have theorized that American indigenous peoples migrated from East Asia. ${ }^{25,26}$ This particular migration relationship was not apparent in this KIR analysis, as the KIR genetic phenotypes of indigenous groups were not similar to East and West Asian populations (Table 2). ${ }^{8}$ Alternatively, the immune systems of indigenous populations may have evolved in convergent manner due to the long-term infectious selection pressure on them by indigenous infectious agents. In support of this theory, archeological evidence indicates that before the arrival of the Europeans; indigenous peoples were more likely subject to bacterial and parasitic infections, such as tuberculosis and pneumonia, as opposed to viral infections. ${ }^{27}$

Lastly, the similarity in KIR genotypes may be the result of an abrupt immune selection following the sudden introduction of novel infectious agents. During the European colonization, viral infections including smallpox, measles and influenza introduced to indigenous peoples resulted in widespread deaths ranging between 25 and $90 \%$ of these populations throughout the Americas. ${ }^{27-30}$ In this scenario, a greater genetic tendency for active/pro-inflammatory immunity could have provided an immunological edge enabling individuals to survive the devastation of 'old world' viral infections. Finally, it may be a combination of these factors that contribute to the KIR cluster similarities within indigenous peoples of the Americas.

Implications for current disease resistance and susceptibility Whatever the mechanism, historically the immune profile of indigenous peoples must have provided a survival advantage suggesting that the prevalence of $B_{\text {telomeric }}$ genes had a particular benefit. Conversely, survival may have been curtailed by $\mathrm{B}_{\text {centromeric genes, }}$ potentially associated with severer forms of autoimmune disease and diabetes. ${ }^{31,32}$

This immunological legacy would also be evident in existing disease patterns, although interactions with recent environmental influences may render these gene profiles less beneficial. Interestingly, the absence of KIR2DS3 could have implications for current disease manifestations as KIR2DS3 appears protective against certain types of immunemediated disease. ${ }^{33,34}$ However, it is unknown if the presence of the activatory $B_{\text {telomeric }}$ genes increases susceptibility to autoimmune diseases prevalent in indigenous peoples throughout the Americas. ${ }^{35-38}$ Nonetheless, North American Aboriginal ancestry is also associated with a reduced progression to chronic HCV infection. ${ }^{15-18}$ While data on HCV sequelae in other indigenous peoples of the Americas are lacking, the possibility that inherited KIR gene profiles could contribute to these disease patterns is strengthened by the observation that similarities exist between the KIR gene profiles of this Aboriginal cohort and those reported in association with spontaneous clearance of HCV. ${ }^{1,39,40}$

\section{CONCLUSION}

The contribution of KIR genotypes and haplotypes to disease resistance and susceptibility on an individual basis, much less on a population basis, has yet to be deciphered. This assessment of the KIR cluster indicates that Aboriginal peoples have a stronger activation phenotype compared to Caucasians. Other genetic and functional studies support the finding that Aboriginal and other indigenous people have an enhanced pro-inflammatory microenvironment. ${ }^{41-43}$ The uniqueness of this phenotype within these populations suggests that it provided a historical survival advantage and that it currently participates in the resistance to chronic HCV infections observed in North American Aboriginals. In light of current environmental influences, however, this KIR genetic phenotype may also detrimentally contribute to the greater prevalence of chronic immune-mediated disease within the indigenous peoples of the Americas. ${ }^{15-18}$

\section{CONFLICT OF INTEREST}

The authors declare no conflict of interest.

\section{ACKNOWLEDGEMENTS}

This work was supported by CIHR, Aboriginal Peoples' Health Institute Grant \#200360 ANR and the Health Sciences Research Foundation. We would like to thank Claudia Watson, RN, for her assistance with coordinating study participants. We would also like to thank Colleen McRae for her assistance in preparing the manuscript. 
1 Khakoo SI, Thio CL, Martin MP et al: HLA and NK cell inhibitory receptor genes in resolving hepatitis $C$ virus infection. Science 2004; 305: 872-874.

2 Martin MP, Gao X, Lee JH et al: Epistatic interaction between KIR3DS1 and HLA-B delays the progression to AIDS. Nat Genet 2002; 31: 429-434.

3 Luszczek W, Manczak M, Cislo $\mathrm{M}$ et al: Gene for the activating natural killer cell receptor, KIR2DS1, is associated with susceptibility to psoriasis vulgaris. Hum Immunol 2004; 65: 758-766.

4 Yen JH, Lin CH, Tsai WC et al: Killer cell immunoglobulin-like receptor gene's repertoire in rheumatoid arthritis. Scand J Rheumatol 2006; 35: 124-127.

5 Lopez-Vazquez A, Rodrigo L, Martinez-Borra J et al: Protective effect of the HLABw4180 epitope and the killer cell immunoglobulin-like receptor 3DS1 gene against the development of hepatocellular carcinoma in patients with hepatitis $C$ virus infection. J Infect Dis 2005; 192: 162-165.

6 Martin AM, Kulski JK, Gaudieri S et al: Comparative genomic analysis, diversity and evolution of two KIR haplotypes A and B. Gene 2004; 335: 121-131.

7 Li H, Pascal V, Martin MP, Carrington M, Anderson SK: Genetic control of variegated KIR gene expression: polymorphisms of the bi-directional KIR3DL1 promoter are associated with distinct frequencies of gene expression. PLoS Genet 2008; 4: e1000254.

8 Yawata M, Yawata N, Abi-Rached L, Parham P: Variation within the human killer cell immunoglobulin-like receptor (KIR) gene family. Crit Rev Immunol 2002; 22 : 463-482.

9 Kulkarni S, Martin MP, Carrington M: The Yin and Yang of HLA and KIR in human disease. Semin Immunol 2008; 20: 343-352.

10 Martin MP, Pascal V, Yeager M et al: A mutation in KIR3DS1 that results in truncation and lack of cell surface expression. Immunogenetics 2007; 59: 823-829.

11 Hsu KC, Chida S, Dupont B, Geraghty DE: The killer cell immunoglobulin-like receptor (KIR) genomic region: gene-order, haplotypes and allelic polymorphism. Immunol Rev 2002; 190: 40-52.

12 Norman PJ, Abi-Rached L, Gendzekhadze $\mathrm{K}$ et al: Meiotic recombination generates rich diversity in NK cell receptor genes, alleles, and haplotypes. Genome Res 2009; 19: 757-769.

13 Miller CL, Strathdee SA, Spittal PM et al: Elevated rates of HIV infection among young Aboriginal injection drug users in a Canadian setting. Harm Reduct J 2006; 3: 9-12.

$14 \mathrm{Wu} \mathrm{HX}$, Wu J, Wong T et al: Incidence and risk factors for newly acquired hepatitis $C$ virus infection among Aboriginal versus non-Aboriginal Canadians in six regions, 1999-2004. Eur J Clin Microbiol Infect Dis 2007; 26: 167-174.

15 Minuk GY, Uhanova J: Viral hepatitis in the Canadian Inuit and First Nations populations. Can J Gastroenterol 2003; 17: 707-712.

16 Minuk GY, Zhang M, Wong SG et al: Viral hepatitis in a Canadian First Nations community. Can J Gastroenterol 2003; 17: 593-596.

17 Grebely J, Raffa JD, Lai C, Krajden M, Conway B, Tyndall MW: Factors associated with spontaneous clearance of hepatitis $\mathrm{C}$ virus among illicit drug users. Can J Gastroenterol 2007; 21: 447-451.

18 Dawood M, Smart G, Wood M, Wu HX, Paton S, Wu J: Hepatitis C virus infection among First Nation and non-First Nation people in Manitoba, Canada: a public health laboratory study. Can J Microbiol 2006; 52: 999-1005.

19 Flores AC, Marcos CY, Paladino N et al: KIR genes polymorphism in Argentinean Caucasoid and Amerindian populations. Tissue Antigens 2007; 69: 568-576.

20 Gutierrez-Rodriguez ME, Sandoval-Ramirez L, Diaz-Flores M et al: KIR gene in ethnic and Mestizo populations from Mexico. Hum Immunol 2006; 67: 85-93.

21 Norman PJ, Carrington CV, Byng M et al: Natural killer cell immunoglobulin-like receptor (KIR) locus profiles in African and South Asian populations. Genes Immun 2002; 3: 86-95.
22 Ashouri E, Farjadian S, Reed EF, Ghaderi A, Rajalingam R: KIR gene content diversity in four Iranian populations. Immunogenetics 2009; 61: 483-492.

23 Niokou D, Spyropoulou-Vlachou M, Darlamitsou A, Stavropoulos-Giokas C: Distribution of killer cell immunoglobulin-like receptors in the Greek population. Hum Immunol 2003; 64: 1167-1176.

24 Gendzekhadze K, Norman PJ, Abi-Rached L, Layrisse Z, Parham P: High KIR diversity in Amerindians is maintained using few gene-content haplotypes. Immunogenetics 2006; 58: 474-480.

25 Williams RC, Steinberg AG, Gershowitz H et al: GM allotypes in Native Americans: evidence for three distinct migrations across the Bering land bridge. Am J Phys Anthropol 1985; 66: 1-19.

26 Rickards O, Tartaglia M, Martinez-Labarga C, De Stefano GF: Genetic relationships among the Native American populations. Anthropol Anz 1994; 52: 193-213.

27 Jones DS: The persistence of American Indian health disparities. Am J Public Health 2006; 96: 2122-2134.

28 Bianchine PJ, Russo TA: The role of epidemic infectious diseases in the discovery of America. Allergy Proc 1992; 13: 225-232.

29 Sessa R, Palagiano C, Scifoni MG, di Pietro M, Del Piano M: The major epidemic infections: a gift from the Old World to the New? Panminerva Med 1999; 41: 78-84.

30 Houston CS, Houston S: The first smallpox epidemic on the Canadian Plains: in the fur-traders' words. Can J Infect Dis 2000; 11: 112-115.

31 Lorentzen AR, Karlsen TH, Olsson M et al: Killer immunoglobulin-like receptor ligand HLA-Bw4 protects against multiple sclerosis. Ann Neurol 2009; 65: 658-666.

32 Jobim M, Chagastelles P, Salim PH et al: Association of killer cell immunoglobulin-like receptors and human leukocyte antigen-C genotypes in South Brazilian with type 1 diabetes. Hum Immunol 2010; 71: 799-803.

33 Miyashita R, Tsuchiya N, Yabe T et al: Association of killer cell immunoglobulin-like receptor genotypes with microscopic polyangiitis. Arthritis Rheum 2006; 54: 992-997.

34 Shastry A, Sedimbi SK, Rajalingam R, Rumba I, Kanungo A, Sanjeevi CB: Different KIRs confer susceptibility and protection to adults with latent autoimmune diabetes in Latvian and Asian Indian populations. Ann NY Acad Sci 2008; 1150: 133-138.

35 Mauldin J, Cameron HD, Jeanotte D, Solomon G, Jarvis JN: Chronic arthritis in children and adolescents in two Indian health service user populations. BMC Musculoskelet Disord 2004; 5: 30.

36 Yoshida EM, Riley M, Arbour LT: Autoimmune liver disease and the Canadian First Nations Aboriginal Communities of British Columbia's Pacific Northwest. World J Gastroenterol 2006; 12: 3625-3627.

37 Ferucci ED, Templin DW, Lanier AP: Rheumatoid arthritis in American Indians and Alaska Natives: a review of the literature. Semin Arthritis Rheum 2005; 34: 662-667.

38 Peschken CA, Esdaile JM: Systemic lupus erythematosus in North American Indians: a population based study. J Rheumatol 2000; 27: 1884-1891.

39 Paladino N, Flores AC, Marcos CY et al: Increased frequencies of activating natural killer receptors are associated with liver injury in individuals who do not eliminate hepatitis C virus. Tissue Antigens 2007; 69 (Suppl 1): 109-111.

40 Montes-Cano MA, Caro-Oleas JL, Romero-Gomez M et al: HLA-C and KIR genes in hepatitis C virus infection. Hum Immunol 2005; 66: 1106-1109.

41 Aborsangaya K, Dembinski I, Khatkar S, Alphonse M, Nickerson P, Rempel JD: The impact of Aboriginal ethnicity on HCV Core induced IL-10 synthesis: interaction with IL-10 gene polymorphisms. Hepatology 2007; 45: 623-630.

42 Rempel JD, Agborsangaya KB, Alphonse MP, Minuk GY: The influence of North American Aboriginal ethnicity on pro-inflammatory and anti-inflammatory cytokine responses to IFN-alpha. J Viral Hepat 2009; 16: 292-297.

43 Larcombe L, Rempel JD, Dembinski I, Tinckam K, Rigatto C, Nickerson P: Differential cytokine genotype frequencies among Canadian Aboriginal and Caucasian populations. Genes Immun 2005; 6: 140-144.

Supplementary Information accompanies the paper on European Journal of Human Genetics website (http://www.nature.com/ejhg) 